
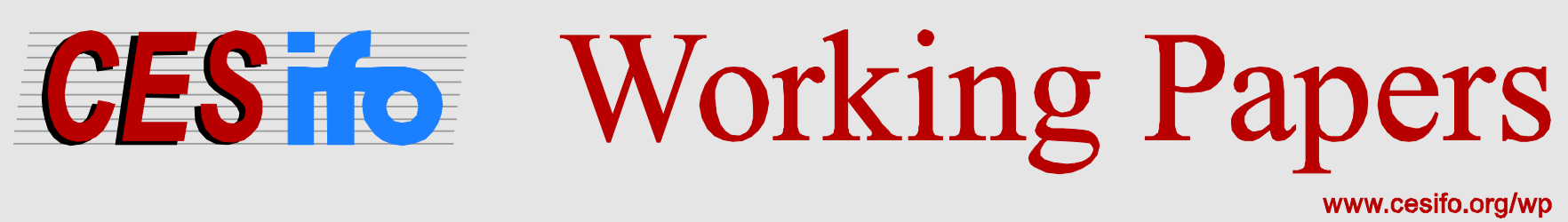

\title{
Gender Equality in Muslim-Majority Countries
}

\author{
Moamen Gouda \\ Niklas Potrafke
}

\author{
CESIFO WORKING PAPER NO. 5883 \\ CATEgory 2: Public CHOICE \\ MAY 2016
}
An electronic version of the paper may be downloaded
- from the SSRN website:
- from the RePEc website:
- from the CESifo website:
www.SSRN.com
Www.RePEc.org
www.CESifo-group.org/wp




\title{
Gender Equality in Muslim-Majority Countries
}

\begin{abstract}
Discrimination has been documented against women in Muslim-majority countries. Constitutions differ among Muslim-majority countries. By using women's rights indicators and exploiting cross-country variation, we find that discrimination against women is more pronounced in countries where Islam is the source of legislation. Constitutions changed in only four Muslim-majority countries since 1980. We discuss anecdotal evidence to what extent women's rights changed as a consequence of new constitutions. Empirical studies should thus distinguish between types of Muslim-majority countries.
\end{abstract}

JEL-Codes: D630, I390, J160, O110, Z120.

Keywords: gender equality, countries with Muslim majority, Al-Azhar's Islamic constitution.

Moamen Gouda

Graduate School of International \& Area Studies

Hankuk University of Foreign Studies

107 Imun-ro, Dongdaemun-gu

South Korea - Seoul 130-791

moamengouda@yahoo.com
Niklas Potrafke

Ifo Institute - Leibniz Institute for

Economic Research

at the University of Munich

Poschingerstrasse 5

Germany - 81679 Munich

potrafke@ifo.de

April 2016

This paper has been accepted for publication in Economic Systems. 


\section{Introduction}

In Afghanistan, discrimination against women has exacerbated. On 4 February 2014, the British newspaper The Guardian published an article "New Afghanistan law to silence victims of violence against women”. The journalist Emma Graham-Harrison describes: “A new Afghan law will allow men to attack their wives, children and sisters without fear of judicial punishment, undoing years of slow progress in tackling violence in a country blighted by so-called "honour" killings, forced marriage and vicious domestic abuse.”3 This law was passed about one year after a fatwa issued by the local Afghani ulema (religious council) banning women from leaving home without a male companion. ${ }^{4}$ In Afghanistan school girls have also been killed for going to school. Discrimination against women is not a local Afghani phenomenon.

Surveys have shown that discrimination against women is widely accepted among many Muslim-majority countries. In 2013, the Pew research center conducted a global survey in 39 Muslim-majority countries, involving more than 38,000 face-to-face interviews in more than 80 languages. The results show that $85 \%$ of Muslims believe that wives should always subservient to and obey their husbands. ${ }^{5}$ In a survey from the University of Michigan's Institute for Social Research, conducted in seven Muslim-majority countries, some one half of the respondents in Tunisia, Turkey and Lebanon replied that women should be permitted to decide for themselves what to wear. In Iraq, Pakistan and Egypt, 27\%, 22\%, and 14\% of the respondents agreed that women should be permitted to decide for themselves what to wear. ${ }^{6}$

Women have been shown to be discriminated against in Muslim-majority countries. Girls and women are discriminated against, for example, in the education system and the labor market, and in electoral participation (Donno and Russett 2004, Norton and Tomal 2009, Cooray and Potrafke 2011, Cooray 2012, Kilby and Scholz 2011, Potrafke and Ursprung 2012, Cho 2013, Del

\footnotetext{
${ }^{3}$ http://www.theguardian.com/world/2014/feb/04/afghanistan-law-victims-violence-women/print

${ }^{4}$ http://in.reuters.com/article/2013/07/20/afghanistan-edict-taliban-women-idINDEE96J01N20130720

${ }^{5}$ http://www.pewforum.org/2013/04/30/infographic-the-worlds-muslims-religion-politics-and-society/

${ }^{6}$ http://www.pewresearch.org/fact-tank/2014/01/08/what-is-appropriate-attire-for-women-in-muslim-countries/
} 
PradoLu 2013, Cooray and Klasen 2014, Salahodjaev and Azam 2015). ${ }^{7}$ To establish these results, scholars have used cross-country data and examined gender equality in countries with Muslim, Christian, etc., majorities. Compared to countries with, for example, a Christian majority, gender discrimination is pronounced in countries with Muslim majorities. The prior empirical studies ignore differences across countries with Muslim majorities.

Gutmann and Voigt (2015) advance empirical research on gender equality in Islamic countries by introducing a new Islamic State Index. Women’s rights are measured by de jure and de facto variables. The authors self-compiled the de jure variables on women's economic rights, rights to a job, inheritance and ownership rights. The de facto rights are measured by the Cingranelli-Richards (CIRI) Human Rights Dataset, which encompasses women’s economic, social and political rights. The results show that women are discriminated against in countries where adherence to Islam is intense; in particular, women's social rights are poor. The sample includes countries with Muslim majorities and countries where other religions such as Christianity are predominant. The Islamic State Index of Gutmann and Voigt (2015) has however some shortcomings. For example, the authors explain that "membership in the Organisation of Islamic Cooperation (OIC) indicates that the governments of the member countries explicitly want their state to be recognized as Islamic” (2015: 358). The authors' index assumes one point for each of the following criteria that are met: Islam is constitutionally prescribed as state religion, the country investigated has a Muslim-majority, or it is a member of OIC (2015: 359-360). OIC membership does however not indicate that members would like to be recognized as Islamic. In fact, 22 of the 57 OIC member countries explicitly declare in the constitutions that they are secular states. ${ }^{8}$ Eight

\footnotetext{
${ }^{7}$ The discrimination against women notwithstanding, experts disagree whether it is oil or Islam that predicts gender inequality (e.g., Ross 2008). Countries with Muslim majorities enjoy less freedom and are less democratic than countries in which Muslims are a minority (Lipset 1994, Midlarsky 1998, Barro 1999, Karatnycky 2002, Fish 2002, Donno and Russett 2004, Borooah and Paldam 2007, Rowley and Smith 2009, Kalyvitis and Vlachaki 2012, Potrafke 2012, 2013, Facchini 2010, Voigt 2005). On economic performance in Islamic countries, see also Hillman (2007a). For an overview of the relation between democracy and economic development, see Hillman (2007b).

${ }^{8}$ These countries are: Azerbaijan, Bangladesh, Benin, Burkina Faso, Cameroon, Chad, Cote D'Ivoire, Gabon, Gambia, Guinea, Guinea-Bissau, Guyana, Kazakhstan, Kyrgyz Republic, Mali, Niger, Nigeria, Senegal, Tajikistan, Togo,

Turkey, and Turkmenistan.
} 
other OIC members do not refer to any Islamic notion in their constitutions (Ahmed and Gouda forthcoming). ${ }^{9}$ The OIC charter does not mention Islamic law or Shari'a. ${ }^{10}$

Islamic Shari'a includes the teaching of the Quran and the teachings of Prophet Mohamed. There are elements in Islamic Shari'a that are clear cut and where there is little room for interpretation. Islamic apologists postulate that Islam mandates a divinely-ordained system of gender-complementarity (See Stowasser 1987, Doi 1989, Kandiyoti 1991). Mutahhari (1981: 65) describes that, while Islam has not considered there to be an exact similarity or identicalness of rights between men and women, Islam never mandates any preference in favor of men as opposed to women. Thus, Islam has fully observed the principle of equality between men and women. Khan (2008: i) describes that, "Islam was the first religion formally to grant the women a status never known before. The Holy Quran, the sacred scripture of Islam, contains hundreds of teachings, which apply both to men and women alike. The moral, spiritual and economic equality of men and women as propagated by Islam is unquestionable.”

Many other scholars describe however that Islam is inimical to women's rights (Sabbah 1985, Ghoussoub 1987, An-Na’im 1990, 2008, Syed et al. 2009). For example, the testimony of a woman is equal half that of a man, "because of the deficiency of [the woman's] intelligence" (Bukhari, 1997: 210). Women could be married at a very early age, as Prophet Muhammad married Aisha when she was 9 years old (Muslim 2014). Under Islamic laws of inheritance, a woman receives less than the share of a man when both have the equal degree of relationship to the deceased person (An-Na'im, 1990: 176). Mir-Hosseini (2003: 3) maintains that gender inequality is taken for granted, a priori, as a principle in classical Islamic jurisprudence (Fiqh) texts. Sharabi (1988) argues that a woman is created to bear and rear children; in the Islamic divine plan, this is her primary role and main contribution to society. The very notion of "women's rights"-as we perceive it today—has no place and little relevance. The hypothesis to be tested empirically is that discrimination against women is more pronounced where Islam is the source of legislation.

\footnotetext{
${ }^{9}$ These countries are: Albania, Indonesia, Lebanon, Mozambique, Sierra Leone, Surinam, Uganda, and Uzbekistan.

${ }^{10} \mathrm{http}: / /$ www.oic-oci.org/oicv2/page/?p_id=53\&p_ref=27\&lan=en
} 
The papers most closely related to our study are Rahman (2012) and Spierings et al. (2009). Rahman (2012) introduces a measure of how a state incorporates Shari'a family law in the legal code, and examines to what extent including Shari'a family law influences gender equality in Muslim-majority countries. The sample includes up to 51 countries. The dependent variables are the share of women's enrolment in higher education, the share of women in the national parliament, and the share of women in the non-agricultural labour force. The most important explanatory variable, Shari'a Family Law is based on two issue areas: the right to divorce and child custody. The Shari'a Family Law variable assumes values from 1 (lax incorporation of Shari'a family law) and 3 (strong incorporation). The results show that the more intense Shari'a Family Law is included in the legal code, the lower are the shares of women's enrolment in higher education, in the national parliament and in the non-agricultural labour force. Spierings et al. (2009) employ a sample of 45 Muslim-majority countries and explore women's labor market participation (LMP). The authors use women's absolute and relative LMP as dependent variables. Absolute women's LMP is measured as women's participation in the formal non-agricultural economy in the year 2000. Relative women's LMP is the ratio of women's and men's absolute LMP and hence a measure for gender equality. As an explanatory variable the authors include among others "state islamization" which is based on content analysis of the 1996/1997 constitutions of the countries included. The state islamization variable assumes seven values: “(0) Secular countries; (1) Islam is mentioned as a historical part of the country; (2) Islamic state religion, which guarantee freedom of religion; and subsequently, one point was added for the mentioning of each of the following four items: the country is called an "Islamic State", only Muslims can become head of state, the shari'a is the foundation for other laws, religious freedom is not guaranteed” (p. 509). Simultaneous equations models show that state islamization indirectly reduced women's relative LMP, via political institutions.

Our sample also includes Muslim-majority countries. We use women's rights indicators exploiting variation across countries and show that women are discriminated against in countries 
where Islam is the source of legislation. Because constitutions changed in only four Muslimmajority countries since 1980, panel data studies are not yet useful in examining to what extent women's rights changed as a consequence of new constitutions.

Section 2 describes the data on Islam as source of legislation and women's rights and gender equality, and shows descriptive statistics and correlations. Section 3 describes the empirical model. Section 4 shows the results. Section 5 discusses anecdotal evidence to what extent women's rights changed as a consequence of new constitutions. Section 6 concludes that empirical studies should thus distinguish between types of Islamic countries.

\section{Data}

\subsection{Islam as source of legislation}

To measure whether Islam is the source of legislation of Muslim-majority countries, we investigate data on Islamic clauses in constitutions of OIC members of the "Characteristics of National Constitutions” dataset, developed by Comparative Constitutions Project. We codify these clauses using the methodology of the Islamic Constitutions Index (ICI) dataset (Ahmed and Gouda, forthcoming). The Islamic Constitutions Index (ICI) dataset uses a unique Islamic constitution, developed by the Al-Azhar University in 1978, as a point of reference to examine distinctive Islamic characteristics in constitutions of OIC members. ${ }^{11}$ We compile a measure related to Islam as a source of legislation in the year 1999. We refer to the year 1999 because some of our dependent variables are measured in the year 2000 (see section 2.2). ${ }^{12}$ The ICI dummy variable assumes the value one when the constitution identifies Islam as a source of legislation, and zero otherwise. In the OIC countries, the Islam source of legislation variable does not vary over the

\footnotetext{
${ }^{11}$ The criteria for membership under the OIC Charter, Article 3(2), are that a country has a "Muslim majority” and that the OIC's Council of Foreign Ministers approves the new member by consensus. The membership of countries with a Muslim minority (e.g. Gabon, Uganda and Benin) is therefore not in accordance with the provisions on membership of the OIC Charter. In any event, we include all OIC members in our sample for consistency.

${ }^{12}$ Cote D'Ivoire is not included in our sample because it joined OIC in the year 2001. Palestine is also excluded because it is not generally recognized as a state internationally.
} 
period $1980-2000{ }^{13}$ In our sample, Islam is the source of legislation in 14 countries. These countries are all Arab except Afghanistan, Iran, and Maldives (see Table A1). ${ }^{14}$ With the exception of Bahrain, all Gulf States’ constitutions identify Islam as a source of legislation. ${ }^{15}$ By contrast, among the six North African countries, only Egypt's constitution identifies Islam as a source of legislation. $^{16}$

For robustness tests, we also employ a measure for the supremacy of Islam within constitutions of OIC members using the methodology developed by Ahmed and Gouda (forthcoming). In countries where Islam is the source of legislation, the supremacy of Islam variable assumes categorical values from 1 (Supremacy of Islam is low) to 5 (Supremacy of Islam is high). The supremacy of Islam variable assumes the value zero when Islam is not the source of legislation (see Table A2). We again refer to the year 1999. With the exception of Iraq, Maldives, Mauritania, and Syria, there were no changes in supremacy of Islam over the period 1980-2000.

Supremacy of Islam was pronounced in the constitutions of Afghanistan, Saudi Arabia and Yemen (the supremacy of Islam variable assumes the value 5). For Iran, Oman, Qatar, Sudan and Syria the supremacy of Islam variable assumed the value 4. Islam was not the source of legislation in countries such as Turkey and the Central Asian countries that expressed deep commitments to secularism in their constitution. In fact, governments in Tajikstan and Uzbekistan suppressed the free exercise of Islam (Ahmed and Gouda forthcoming).

\subsection{Women's rights and gender equality}

To measure gender equality, we use the Cingranelli-Richards (CIRI) Human Rights Dataset which encompasses women's economic rights such as rights for equal pay and work, women's social

\footnotetext{
${ }^{13}$ Mauritania is an exception. Islam became the source of legislation only in 1991.

${ }^{14}$ We define Arab countries as member states of the Arab League. See http://www.lasportal.org/

${ }^{15}$ Gulf States are member states of Gulf Cooperation Council (GCC). These countries are Bahrain, Kuwait, Oman, Qatar, Saudi Arabia, and United Arab Emirates. See http://www.gcc-sg.org/eng/indexc64c.html?action=GCC. In 1999, however, there was no constitution in Bahrain and Pakistan; and we therefore cannot include Bahrain and Pakistan in our empirical model.

${ }^{16}$ The United Nations definition of North Africa includes seven countries or territories; Algeria, Egypt, Libya, Morocco, Sudan, Tunisia, and Western Sahara. See http://millenniumindicators.un.org/unsd/methods/m49/m49regin.htm
} 
rights including, for example, the right for equal inheritance and equal marriage, and women's political rights including, for example, the right to vote and run for political office. The CIRI indices assume values between 0 (minimum of women's rights) and 3 (maximum of women’s rights). In the baseline model, we use the average of the women's economic rights and women's social rights indicator over the period 2001-2010. We do not use the CIRI indices in an individual year such as 2000 or 2001 because the CIRI indices may well be low/high in individual years and countries.

We also use the Social Institutions and Gender Index (SIGI) compiled by the OECD (cf. Branisa et al. 2009, 2014), which has been described as follows: "The innovation of SIGI is that it shows how social institutions affect gender inequality; thus, it focuses not on gender outcomes, but on institutions that affect such outcomes” (Klasen and Schüler 2011: 8). The SIGI is based on twelve institutional variables that are compiled in the OECD Gender, Institutions and Development database and roughly refer to the year 2000 (the data are available for only this year). The SIGI is based on five sub-indices: family code, civil liberties, physical integrity, son preference, and ownership rights. The final values range between 0 and 1 . The five dimensions of social institutions are then aggregated by computing the average of the squares of the sub-indices which range from 0 (no inequality) to 1 (complete inequality). We employ in our econometric model the reverse of the SIGI (i.e. 1 - SIGI), which ranges from 0 (complete inequality) to 1 (equality).

The CIRI gender equality indices are available for up to 56 Muslim-majority countries. The samples are somewhat smaller when using the SIGI and its sub-indices. Table A4 shows the correlation coefficients between the gender equality indices. The source of legislation variable is available for 53 Muslim-majority countries in 1999. 


\subsection{Descriptive statistics}

To illustrate the correlation between gender equality and intensity of Islam, we first present descriptive statistics of the CIRI on women's rights and the reversed SIGI in countries where Islam is the source of legislation and other countries. Figure 1 shows that women's economic rights differ somewhat in countries where is Islam is the source of legislation (0.79) and in countries where Islam is not the source of legislation (0.92). By contrast, women's political rights differ a great deal in countries where is Islam is the source of legislation (1.26) and in countries where Islam is not the source of legislation (1.84). Also, women’s social rights differ (0.36 and 0.67).

Figure 2 shows that gender equality as measured by the reversed overall SIGI is 0.68 in countries where is Islam is the source of legislation and 0.83 in countries where Islam is not the source of legislation. We reject the null hypothesis that the means of the SIGI in both samples do not differ with a t-value of 2.96 (the reversed SIGI assumes values between 0.32 and 1.00 in our sample). The reversed family code sub-index hardly differs in countries where is Islam is the source of legislation (0.49) and in countries where Islam is not the source of legislation (0.53). There is a stark difference in the civil liberties sub-index (0.38 and 0.77).

Figure 3 shows the differences in the sub-indices for physical integrity (0.48 and 0.55$)$, son preference (0.52 and 0.88) and ownership rights (0.58 and 0.60).

\section{The empirical model}

The basic econometric model has the following form:

$$
\begin{aligned}
& \text { Gender equality Index } x_{i j}=\alpha_{\mathrm{j}} \text { Islam source of legislation }{ }_{i}+\Sigma_{k} \beta_{j k} x_{i k}+u_{i j} \\
& \text { with } \mathrm{i}=1, \ldots, 53 ; \mathrm{j}=1, . ., 9 ; \mathrm{k}=1, \ldots, 5
\end{aligned}
$$

The dependent variable Gender equality Index $x_{i j}$ describes gender equality in country $i$ for index $\mathrm{j}$ (women's economic, political and social rights, the reversed SIGI, and the five sub-indices of the 
SIGI). The vector $\boldsymbol{x}_{i}$ contains five control variables: the share of Muslim population, the logarithm of per capita GDP, a democracy variable, a globalization variable and an oil production variable. The share of Muslim population is by Parker (1997). Discrimination against women is likely to be more pronounced when the share of Muslims is large. By contrast, discrimination against women may be less pronounced when GDP per capita is high and when the country is democratic. Political institutions are measured by the Democracy-Dictatorship dummy variable by Cheibub et al. (2010) which has been used in several empirical studies (e.g., Berdiev et al. 2012, Kalyvitis and Vlachaki 2012, Rode and Gwartney 2012, Rode 2013, Bjørnskov and Rode 2014, Rode and Revuelta 2015). ${ }^{17}$ The variable assumes the value one for democracies and zero otherwise. The data by Cheibub et al. (2010) are available till 2008 and we therefore use the average democracy score over the period 2001-2008 which assumes values between 0 and 1 . Globalization is measured by KOF index of globalization and included because globalization has been shown to promote gender equality (see Potrafke 2015 for an encompassing survey on the consequences of globalization). We also include an oil production value (per capita) because gender equality has been shown to be lower in countries where oil production is pronounced. ${ }^{18}$ GDP per capita, globalization, and oil production refer to the average of the annual data over the period 2001-2010. Table A3 shows descriptive statistics of all variables. We estimate the model with ordinary least squares (OLS) and robust standard errors.

To be sure, we acknowledge that up to 53 observations describe a small sample and that the properties of the OLS estimator only hold for a large number of observations. We therefore keep

\footnotetext{
${ }^{17}$ The more traditional measures of democracy were the POLITY IV and the Freedom House indices. These indices have, however, been criticized on several grounds (Munk and Verkuilen 2002, Vreeland 2008, Cheibub et al. 2010). Criticisms include that the previous indices have been based on subjective evaluations and inadequate operational rules and that the middle categories are hardly useful to distinguish between political regimes. The Democracy-Dictatorship variable by Cheibub et al. (2010) distinguishes between regimes in which executive and legislative offices are allocated in contested elections and those regimes in which this is not the case.

${ }^{18}$ We use the data on oil production by the U.S. Energy Information Administration (EIA). To compute a nominal oil production value (per capita), we use the following formula: [EIA crude oil production (1000 barrels per day)*365*crude oil spot price (US\$ per barrel)*1000]/Population. We measure the crude oil spot price as the average of the Brent spot price (US\$ per barrel) and the West Texas Intermediate spot price (US\$ per barrel) as provided by the EIA. We convert the nominal oil production value into real terms (constant 2000 US\$) by using the US GDP deflator as employed by Michael L. Ross. We use populations reported in the World Bank's World Development Indicators.
} 
the number of explanatory variables small to not further reduce the degrees of freedom. We also acknowledge that explanatory variables such as the log of GDP, democracy and globalization may well be endogenous and including these explanatory variables may well give rise to biased estimates. Not including the log of GDP, democracy and globalization is, however, likely to give rise to omitted variable bias. That is why we show results including/excluding the log of GDP, democracy and globalization. Inferences regarding the Islam source of legislation variable do not change.

\section{Results}

\subsection{Basic results}

Table 1 shows the regression results for the Women's Economic Rights index. The Islam source of legislation variable does not turn out to be statistically significant in columns (1) to (6). Log per capita GDP has the expected positive sign and is statistically significant at the $1 \%$ level in column (4) and at the $10 \%$ level in column (6). By contrast, the Islam source of legislation variable is statistically significant at the $1 \%$ and $5 \%$ levels in Table 2 when the Women's Political Rights index is used. When we include all control variables, the Islam source of legislation variable is statistically significant at the $1 \%$ level (column 6). The numerical meaning of the effect is that women's political rights are about 0.36 points lower in countries where Islam is the source of legislation as compared to countries where Islam is not the source of legislation. The Muslim share and oil production variables have the expected negative signs and are statistically significant at the 5\% level. Table 3 shows that the Islam source of legislation variable does not turn out to be statistically significant when we use Women’s Social Rights Index as dependent variable.

Table 4 shows the results when we use the reversed SIGI as dependent variable. When we include all control variables, the Islam source of legislation variable is statistically significant at the 5\% level (column 6). The numerical meaning of the effect is that gender equality as measured by the reversed SIGI (on a scale from 0.32 to 1 ) is about 0.16 points lower in countries where Islam is 
the source of legislation as compared to countries where Islam is not the source of legislation. Log per capita GDP has the expected positive sign and is statistically significant at the $5 \%$ level in columns (3) and (4). The KOF globalization index has the expected positive sign and is statistically significant at the 5\% level in columns (5) and (6) (e.g., Potrafke and Ursprung 2012). The other control variables do not turn out to be statistically significant.

Tables 5 to 9 show the results for the SIGI sub-indices. Table 5 shows the results when we use the reversed family code sub-index as dependent variable. The Islam source of legislation variable is statistically significant at the $5 \%$ level in columns (3) and (4), and at the $10 \%$ level in column (5). When all control variables are included, the Islam source of legislation variable does not turn out to be significant. The Islam source of legislation variable is statistically significant in Tables 6 to 8, but lacks statistical significance in Table 9 when the reversed ownership rights subindex is used. The numerical meaning of the effects in Table 6, 7 and 8 in column (6) is that gender equality as measured by the reversed civil liberties sub-index (on a scale from 0 to 1 ) is about 0.38 points, as measured by the reversed physical integrity sub-index (on a scale from 0.03 to 0.96 ) about 0.18 points, and as measured by the reversed son-preference sub-index (on a scale from 0 to 1) about 0.26 points lower in countries where Islam is the source of legislation as compared to countries where Islam is not the source of legislation.

\subsection{Robustness checks}

We checked the robustness of the results in several ways. We only included Muslim-majority countries for which the Muslim share as measured by Parker (1997) is larger than 50 percent (39 out of the 53 countries in the baseline model). Inferences do not change.

We replaced the dummy variable Islam source of legislation by the variable which measures its degree of supremacy of Islam when it is the source of legislation. The results corroborate the inferences based on the baseline model: The degree of supremacy of Islam variable is statistically 
significant when we use all the CIRI indices and five out of the six SIGI indices as dependent variables.

We used the CIRI indices as measured over the periods 2001-2005 and 2006-2010. Inferences do not change.

It is conceivable that the level of education, and perhaps in the case of the current sample, the level of male education is correlated with gender equality. An issue is how to measure the level of education distinguished by gender. We included average years of total schooling from the BarroLee (2013) database. Because we use averages over the period 2001-2010 in our baseline model, we include the average of Barro and Lee's data for the years 2005 and 2010. We used average years of total schooling in \% of population aged 15 and over and in \% of population aged 25 and over, each for males and females together and males only. The Barro-Lee variables are available for 42 of the 56 Muslim-majority countries. Including the Barro-Lee education variables thus reduces our samples. The Barro-Lee education variables have the expected positive sign (except when we use women's political rights as dependent variable) and are statistically significant in many specifications. Gender equality was pronounced in countries with quite high average years of total schooling. Inferences regarding the Islam source of legislation variables hardly change. Compared to our baseline model, the Islam source of legislation variables lack statistical significance in Tables 5 and 7. When we use the reversed son preference sub-index as dependent variable and include all explanatory variables, both the Barro-Lee variables and the Islam source as legislation variables lack statistical significance.

\section{Changes over time: anecdotal evidence}

The cross-sectional results ignored changes over time. Over the period 1980-2000, supremacy of Islam in constitutions of OIC members changed in Iraq, Maldives, Mauritania, and Syria. Syria was the only country where the degree of supremacy of Islam decreased, while Iraq, Maldives, and Mauritania experienced an increase in supremacy of Islam. Women in Syria have a considerably 
long history of emancipation and gender equality is quite advanced as compared to other Muslimmajority countries. In 1949, Syria was the first Arab country granting women the right to vote. When Syria’s ex-president Hafez al-Assad died in 2000, the Syrian parliament amended the constitution to lower the minimum age for a president from forty to thirty-four in order to allow the current president Bashar to take office. The new president amended the constitution in 2000. As a consequence, the degree of supremacy of Islam decreased. Opinion polls in Syria showed that people were dissatisfied with corruption and political cronyism, held mixed views on the economy but appreciate stability and women's rights (Anderson 2014). Women's presence in the parliament was larger than in most neighboring countries (Kelly and Breslin, 2010). Women’s literacy levels went up from 33 per cent in 1980 to 79 per cent in 1999, reaching 93 per cent in 2011 (UNICEF, 2011).

Mauritania was one of the few countries where Islam became more pronounced in the constitution. Islam became the source of legislation in the Mauritanian constitution only in 1991. The World Economic Forum (2013) describes that women’s legal rights were more restricted than men's legal rights. The Shari'a as applied in Mauritania implies that the testimony of two women is equal to that of one man. Mauritanian courts granted only half as large an indemnity to the family of a woman who was killed as to the family of a man. For commercial and other issues not addressed specifically by Shari’a, the law and courts provided equal treatment between women and men (U.S. Department of State, 2012a). Women in Mauritania inherited less than the share of a man when both have the equal degree of relationship to the deceased person (CEDAW, 2011). There was no specific law criminalizing domestic violence, nor any definition of the latter in the Mauritanian legislation. Moreover, there were no specific laws addressing sexual harassment, although women's rights groups and the Mauritanian government both reported sexual harassment as a common problem in the workplace (U.S. Department of State, 2012b).

Before the ratification of the 2005 constitution, Iraqi women had enjoyed some of the most modern legal protections in the Arab and Muslim world, under a civil code that prohibits marriage 
below the age of 18, arbitrary divorce and male favouritism in child custody and property inheritance disputes (Constable, 2004). However, article 41 of Iraq’s 2005 Constitution allowed each religious group in Iraq to govern its own personal status matters. As a result, the situation of Iraqi women still very much depends on the implementation of Islamic law and on the priorities of male religious authorities. When the security situation in Iraq deteriorated, violence against women became more pronounced-especially rapes, honor killings, and kidnapping-forcing women to stay at home and limiting their educational and employment opportunities (Ahmed, 2010; Sarhan, 2008).

The Asian Development Bank (2007) describes that Maldivian women have been among the most emancipated in South Asia and the Islamic world. There has been no institutional discrimination based on gender in access to education and health services or for jobs in the public sector. School enrollment rates for girls and boys were almost identical, and adult literacy rate was very high (98\%). However the status of women's rights significantly deteriorated after the ratification of the 2008 constitution. Under the 2008 constitution, Maldives became a '100 percent' Muslim country, with a justice system based on a hybrid of common law and Islamic Sharia (Mohamed, 2013). Although the country did not implement many of the 'Hadd' or penalties prescribed by Shari'a, including amputation and stoning, it did practice some selective punishments. One such penalty is the implementation of flogging for a number of crimes including, but not limited to, fornication outside of wedlock. The Maldivian government's own figures showed that 90 per cent of people sentenced to flogging were female, while one in three women between the ages of 15 and 49 have suffered physical or sexual abuse over the period 2007-2012. More than two million people worldwide have signed an online petition on Avaaz.org calling for the country's President, Mohammed Waheed Hassan, who seized power in a coup in 2012, to do more to protect women and children in the country (Merrick, 2013).

The anecdotal evidence indicates that discrimination against women became more pronounced when constitutions became more Islamic and supports the cross-sectional results. 


\section{Conclusion}

Studies using cross-country data including countries with Muslim, Christian etc., majorities, concluded that women and girls are discriminated against in countries with Muslim majorities. Many prior studies do not account for differences across Muslim-majority countries.

We have used information on whether Islam is the source of legislation and examined gender equality in Muslim-majority countries. The results show that discrimination against women is pronounced when Islam is the source of legislation. Empirical studies examining how types of religion such as Islam, Christianity etc. influence human development or institutions should thus distinguish between types of Muslim-majority countries.

Many Islamic scholars propose that there is no discrimination against women in Islam (Sheriff 1989, Al-Shiha 2013, Badawi 1995, Khan 2004). By contrast, our results corroborate that Shari'a is incompatible with the human rights as pertaining to gender equality (An-Na'im 1990, 2008, Baderin 2003, Kuran 2010, Gouda 2013).

We have exploited cross-sectional variation. With only very few changes within both independent variables (Islam source of legislation and supremacy of Islam) over the period 19802000, there is no point yet in estimating a panel data model. Anecdotal evidence however supports the cross-sectional results. By expanding the period of analysis, future research may well use panel data and be able to better disentangle to what extent Islamic constitutions influence women's rights.

\section{Acknowledgements}

We would like to thank Zachary Elkins, Mark Farha, Jerg Gutmann, Shimaa Hanafy, Arye Hillman, Mirjam Künkler, Hélène Landemore, David Law, David Mednicoff, Shylashri Shankar and participants of GSIAS research seminar at Hankuk University of Foreign Studies, the 2015 annual meeting of the Middle East Economic Association, GIGA Seminar in Socio-Economics, "Inclusiveness, Representation, and Religious Accommodation in Constitutions and Constitutionalism” Conference at Center for Interdisciplinary Research, Bielefeld University, for helpful comments. Ha Quyen Ngo has provided excellent research assistance. Moamen Gouda acknowledges financial support from the Hankuk University of Foreign Studies Research Fund. 


\section{References}

Ahmed, D, \& Gouda, M. (forthcoming). Measuring Constitutional Islamization: Insights from the Islamic Constitutions Index. Hastings International and Comparative Law Review.

Ahmed, H. (2010), “Iraq”, In Kelly, S. \& and Breslin, J. (Eds.), Women's Rights in the Middle East and North Africa: Progress amid Resistance. Freedom House / Rowman and Littlefield Publishers, New York / Lanham, pp. 1-35.

Al-Shiha, A. (2013). Women in Islam: The common misconceptions. CreateSpace Independent Publishing Platform.

An-Na'im, A. A. (1990). Towards an Islamic reformation: civil liberties, human rights, and international law. New York: Syracuse University Press.

An-Na'im, A. A. (2008). Islam and the secular state: Negotiating the future of Shari'a. Cambridge, MA: Harvard University Press.

Anderson, T. (2014). "Why Syrians Support Bashar al Assad.” Global Research. September 30, 2014.

Badawi, J. A. (1995). Gender equity in Islam: Basic principles. Indiana: American Trust Publications.

Baderin, M. A. (2003). International human rights and Islamic law. New York: Oxford University Press.

Barro, R. J. (1999). Determinants of democracy. Journal of Political Economy 107, 158-183.

Barro, R. J. \& Lee, J.W. (2013). A new data set of educational attainment in the world, 1950-2010. Journal of Development Economics 104, 184-198.

Berdiev, A.N, Y. Kim, \& Chang, C.-C. (2012). The political economy of exchange rate regimes in developed and developing countries. European Journal of Political Economy 28, 38-53.

Bjørnskov, C., \& Rode, M.D. (2014). Democratic transitions and institutional change: What's behind the association? Aarhus University, Working paper.

Borooah, V.K., \& Paldam, M. (2007). Why is the world short of democracy? A cross-country analysis of barriers to representative government. European Journal of Political Economy 23, 582-604.

Branisa, B., Klasen, S. \& Ziegler, M. (2009). New measures of gender inequality: the social institutions and gender index (SIGI) and its subindices. Courant Research Centre: Poverty, Equity and Growth - Discussion Papers 10, Courant Research Centre PEG. 
Branisa, B., Klasen, S., Ziegler, M., Drechsler, D. \& Jütting, J. (2014). The institutional basis of gender inequality: the social institutions and gender index (SIGI).

Feminist Economics 20, 29-64.

Bukhari, M. I. (1997). The translation of the meanings of Sahih al-Bukhari, 8 vols. Trans. M. M. Khan. Riyadh: Darussalam Publishers \& Distributors. Vol. 7, Book 6, Number 304.

Cheibub, J., Gandhi, J., \& Vreeland, J.R. (2010). Democracy and dictatorship revisited. Public Choice 143, 67-101.

Cho, S.-Y. (2013). Integrating inequality - Globalization, women's rights, son preference and human trafficking. International Studies Quarterly 57, 683-697.

Cingranelli, D.L. \& Richards, D.L. (2010). The Cingranelli-Richards (CIRI) Human Rights Dataset. Available at http://www.humanrightsdata.org.

Committee on the Elimination of Discrimination Against Women (CEDAW) (2011) Summary record of the 1004th meeting CEDAW/C/SR.1004, Geneva.

Constable, P. (2004). “Women in Iraq Decry Decision To Curb Rights”. Washington Post, January 16, 2004.

Cooray, A. (2012). Suffrage, democracy and Gender inequality in education. Oxford Development Studies 40, 21-47.

Cooray, A., \& Potrafke, N. (2011). Gender inequality in education: political institutions or culture and religion? European Journal of Political Economy 27, 268-280.

Cooray, A., \& Klasen, S. (2014). Maternal Mortality, Religion and the Enrolment of Girls and Boys: Is there a Link? Brooks World Poverty Institute Working Paper Series 19714, BWPI, The University of Manchester.

Del PradoLu, S. F. (2013). Women's electoral participation in Muslim majority and nonMuslim majority countries. Journal of International Women's Studies 14, 137-147.

Doi, A. R. (1989). Women in Shari'ah (Islamic Law). London, UK: Taha Publishers Ltd.

Donno, D., \& Russett, B. (2004). Islam, authoritarianism, and female empowerment. World Politics 56, 582-607.

Dreher, A. (2006). Does globalization affect growth? Evidence from a new index of globalization. Applied Economics 38, 1091-1110.

Dreher, A., Gaston, N., \& Martens, P. (2008). Measuring globalization - Gauging its consequences. Springer, Berlin.

Facchini, F. (2010). Religion, law and development: Islam and Christianity - Why is it in occident and not in the orient that man invented the institutions of freedom? European Journal of Law and Economics 29(1), 103-129. 
Fish, S. (2002). Islam and authoritarism. World Politics 55, 4-37.

Kelly, S. \& Breslin, J. (2010), “Syria”, In Kelly, S. \& Breslin, J. (Eds.), Women's Rights in the Middle East and North Africa: Progress amid Resistance. Freedom House / Rowman and Littlefield Publishers, New York / Lanham, pp. 1-28.

Ghoussoub, M. (1987). Feminism - or the eternal masculine- in the Arab world. New Left Review 161, 3-13.

Gouda, M. (2013). Islamic constitutionalism and rule of law: a constitutional economics perspective. Constitutional Political Economy 24, 57-85.

Gutmann, J., \& Voigt, S. (2015). The Rule of Law and Constitutionalism in Muslim Countries. Public Choice 162(3-4), 351-380.

Hillman, A.L. (2007a). Economic and security consequences of supreme values. Public Choice 131(3-4), 259-280. Reprinted as: Hillman, A. L. (2008). An economic perspective on radical Islam. In Frisch, A. \& Inbar, E. (Eds.), Radical Islam and International Security: Challenges and Responses. Routledge, London, pp. 44-69.

Hillman, A.L. (2007b). Democracy and low-income countries. In Casas Pardo, J., \& Schwartz, P. (Eds.), Public Choice and Challenges of Democracy. Edward Elgar, Cheltenham U.K., pp. 277-294.

Kalyvitis, S., \& Vlachaki, I. (2012). When does more aid imply less democracy? An empirical examination. European Journal of Political Economy 28, 132-146.

Kandiyoti, D. (1991), Introduction. In Kandiyoti, D. (Ed.), Women, Islam and the State. Temple University Press, Philadelphia, 1-22.

Karatnycky, A. (2002). Muslim countries and the democracy gap. Journal of Democracy 13, 99-112.

Khan, T. U. (2004). Women's rights in Islam. National Research and Development Foundation (NRDF). Peshawar- Pakistan.

Khan, M. Z. (2008). Woman in Islam. Islam International Publications Limited. Islamabad, Sheephatch Lane, Tilford, Surrey, U.K.

Kilby, C., \& Scholz, S.J. (2011). The impact of globalization on women - Testing Vandana Shiva's critique of development. Villanova University, mimeo.

Klasen, S., \& Schüler, D., 2011. Reforming the Gender-Related Development Index and the Gender Empowerment Measure: Implementing some specific proposals. Feminist Economics 17, 1-30. 
Kuran, T. (2010). The rule of law in Islamic thought and practice: A historical perspective. In J. J. Heckman, R. L. Nelson, \& L. Cabatingan (Eds.). Global perspectives on the rule of law. New York: Routledge, pp. 71-89.

Lipset, S.M. (1994). The social requisites of democracy revisited. American Sociology Review 59, 1-22.

Marshall, M., \& Jaggers, K. (2011). Polity IV Country Reports.

Merrick, J. (2013). “Britons urged to boycott Maldives over sexist laws.” The Independent Midlarsky, M. (1998). Democracy and Islam: Implications for civilizational conflict and the democratic peace . International Studies Quarterly 42, 485-511.

Mir-Hosseini, Z. (2003). The Construction of Gender in Islamic Legal Thought: Strategies for Reform. Hawwa: Journal of Women in the Middle East and the Islamic World, 1/1, pp 1-28.

Mir-Hosseini, Z. (2009). Towards Gender Equality: Muslim Family Laws and the Shari'a. In Zainah Anwar (ed.), Wanted: Equality and Justice in the Muslim Family. Musawah: An Initiative of Sisters of Islam, Selangor, Malaysia, pp. 23-64.

Mohamed, M. (2013). “The culture of flogging in the Maldives: a systematic abuse of human rights.” Minivan News, March 25th, 2013.

Munck, G., \& Verkuilen, J. (2002). Conceptualizing and measuring democracy: Evaluating alternative indices. Comparative Political Studies 55, 5-34.

Muslim, I. A. (2014). Sahih Muslim, being traditions of the sayings and doings of the prophet Muhammad as narrated by his companions and compiled under the title Al-Jami'-us-Sahih. 4 Vols. Trans. Abdul Hamid Siddiqi. USC Center for Muslim-Jewish Engagement website. Accessed on 17/7/2014. http://www.usc.edu/org/cmje/religious-texts/hadith/muslim/008smt.php. Book 008, Numbers 3309; 3310; 3311.

Mutahhari, M. (1981). The rights of women in Islam. $1^{\text {st }}$ ed. Tehran, Iran: World Organization for Islamic Services.

Norton, S.W., \& Tomal, A. (2009). Religion and female educational attainment. Journal of Money, Credit and Banking 41, 961-986.

Parker, P.M. (1997). National cultures of the world: a statistical reference. Greenwood Press. Princeton and Oxford.

Potrafke, N. (2012). Islam and democracy. Public Choice 151, 185-192.

Potrafke, N. (2013). Democracy and countries with Muslim majorities: A reply and update. Public Choice 154, 323-332.

Potrafke, N. (2015). The evidence on globalisation. World Economy 38, 509-552. 
Potrafke, N., \& Ursprung, H.W. (2012). Globalization and gender equality in the course of development. European Journal of Political Economy 28, 399-413.

Rahman, F. Z. (2012). Gender Equality in Muslim-Majority States and Shari'a Family Law: Is There a Link? Australian Journal of Political Science 47(3): 347-362.

Rode, M.D. (2013). Do good institutions make citizens happy, or do happy citizens build better institutions? Journal of Happiness Studies 14, 1479-1505.

Rode, M.D., \& Gwartney J.D. (2012). Does democratization facilitate economic liberalization? European Journal of Political Economy 28, 607-619.

Rode, M.D., \& Revuelta, J. (2015). The wild bunch! An empirical note on populism and economic institutions. Economics of Governance 16, 73-96.

Ross, M.L. (2008). Oil, Islam and women. American Political Science Review 102, 107-123.

Rowley, C.K., \& Smith, N. (2009). Islam’s democracy paradox: Muslims claim to like democracy, so why do they have so little? Public Choice 139, 273-299.

Sabbah, F. A. (1984). Women in the Muslim unconscious. New York: Pergamon Press.

Salahodjaev, R., \& Azam, S. (2015). Intelligence and gender (in)equality: Empirical evidence from developing countries. Intelligence 52, 97-103.

Sarhan, A. (2008). “Hitmen Charge \$100 a Victim.” The Observer. November 30, 2008.

Sharabi, H. (1988). Neopatriarchy: A Theory of Distorted Change in Arab Society. New York: Oxford University Press.

Sheriff, S. (1989). Women's Rights in Islam. London, UK: Taha Publishers Ltd.

Spierings, N, J. Smits, \& Verloo, M. (2009). On the compatibility of Islam and gender equalilty - Effects of modernization, state islamization, and democracy on women's labor market participation in 45 Muslim countries. Social Indicators Research 90, 503-522.

Stowasser, B. F. (1987). Liberated equal or protected dependent? Contemporary religious paradigms on women's status in Islam. Arab Studies Quarterly 9, no. 2, 260-263.

Summers, R., \& Heston, A. (1991). The Penn World Table (Mark 5): an expanded set of international comparisons, 1950-1988. Quarterly Journal of Economics 106, 327-369.

Syed, J., M. Özbilgin, D. Torunoglu and F. Ali (2009). Rescuing gender equality from the false dichotomies of secularism versus shariah in Muslim majority countries. Women's Studies International Forum 32(2): 67-79. http://www.sciencedirect.com/science/article/pii/S0277539509000314

U.S. Department of State (2012a). 2011 Country Reports on Human Rights Practices.

U.S. Department of State (2012b). '2012 Country Reports on Human Rights: Mauritius. (http://www.state.gov/documents/organization/204356.pdf- accessed 16 March 2015). 
UNICEF (2011). Syria: MENA Gender Equality Profile.

Voigt, S. (2005). Islam and the institutions of a free society. Independent Review 10, 59-82.

Vreeland, J.R. (2008). The effect of political regime on civil war: Unpacking anocracy. Journal of Conflict Resolution 52, 401-425.

World Economic Forum (2013). The Global Gender Gap Report 2013. 
Table A1. Countries included

\begin{tabular}{|c|c|}
\hline where Islam is source of legislation & where Islam is not source of legislation \\
\hline Afghanistan & Albania \\
\hline Comoros & Algeria \\
\hline Egypt & Azerbaijan \\
\hline Iran & Bangladesh \\
\hline Kuwait & Benin \\
\hline Maldives & Brunei Darussalam \\
\hline Mauritania & Burkina Faso \\
\hline Oman & Cameroon \\
\hline Qatar & Chad \\
\hline Saudi Arabia & Djibouti \\
\hline Sudan & Gabon \\
\hline Syria & Gambia \\
\hline United Arab Emirates & Guinea \\
\hline \multirow[t]{26}{*}{ Yemen } & Guinea Bissau \\
\hline & Guyana \\
\hline & Indonesia \\
\hline & Iraq \\
\hline & Jordan \\
\hline & Kazakhstan \\
\hline & Kyrgyzstan \\
\hline & Lebanon \\
\hline & Libya \\
\hline & Malaysia \\
\hline & Mali \\
\hline & Morocco \\
\hline & Mozambique \\
\hline & Niger \\
\hline & Nigeria \\
\hline & Senegal \\
\hline & Sierra Leone \\
\hline & Somalia \\
\hline & Suriname \\
\hline & Tajikistan \\
\hline & Togo \\
\hline & Tunisia \\
\hline & Turkey \\
\hline & Turkmenistan \\
\hline & Uganda \\
\hline & Uzbekistan \\
\hline
\end{tabular}


Table A2. Ranking OIC-members' constitutions by level of supremacy of Islam (1999)

\begin{tabular}{|c|c|c|c|}
\hline Constitutions & Score & Constitutions & Score \\
\hline Afghanistan 1990 & 5 & Malaysia 1957 (rev. 1996) & 0 \\
\hline Albania 1998 & 0 & Maldives 1998 & 3 \\
\hline Algeria 1963 & 0 & Mali 1992 & 0 \\
\hline Azerbaijan 1995 & 0 & Mauritania 1991 & 2 \\
\hline Bangladesh 1972 (reinst. 1986) & 0 & Morocco 1970 (rev. 1996) & 0 \\
\hline Benin 1990 & 0 & Mozambique 1990 & 0 \\
\hline Brunei 1959 (rev. 1984) & 0 & Niger 1999 & 0 \\
\hline Burkina Faso 1991 & 0 & Nigeria 1999 & 0 \\
\hline Cameroon 1972 & 0 & Oman 1996 & 4 \\
\hline Chad 1996 & 0 & Qatar 1970 & 4 \\
\hline Comoros 1996 & 2 & Saudi Arabia 1992 & 5 \\
\hline Djibouti 1992 & 0 & Senegal 1963 & 0 \\
\hline Egypt 1971 (rev. 1980) & 3 & Sierra Leone 1991 (reinst. 1996) & 0 \\
\hline Gabon 1991 (rev. 1997) & 0 & Somalia 1979 & 0 \\
\hline Gambia 1996 & 0 & Sudan 1998 & 4 \\
\hline Guinea 1990 & 0 & Surinam 1987 (rev. 1992) & 0 \\
\hline Guinea-Bissau 1984 (rev. 1991) & 0 & Syria 1973 & 4 \\
\hline Guyana 1980 (rev. 1995) & 0 & Tajikistan 1994 & 0 \\
\hline Indonesia 1945 (reinst. 1959) & 0 & Togo 1979 & 0 \\
\hline Iran 1979 (rev. 1989) & 4 & Tunisia 1959 (rev. 1988, 1999) & 0 \\
\hline Iraq 1970 & 0 & Turkey 1982 & 0 \\
\hline Jordan 1952 & 0 & Turkmenistan 1992 & 0 \\
\hline Kazakhstan 1995 (rev. 1998) & 0 & Uganda 1995 & 0 \\
\hline Kuwait 1962 (reinst. 1992) & 3 & United Arab Emirates 1971 (rev. 1996) & 3 \\
\hline Kyrgyz Republic 1993 & 0 & Uzbekistan 1992 & 0 \\
\hline Lebanon 1926 (rev. 1995) & 0 & Yemen 1991 & 5 \\
\hline Libya 1969 (rev. 1977, 1979) & 0 & & \\
\hline
\end{tabular}

Source: Ahmed and Gouda (forthcoming) 
Table A3. Data description and sources.

\begin{tabular}{|c|c|c|c|c|c|c|}
\hline Variable & $\mathbf{N}$ & Mean & Std. Dev. & Min & Max & Source \\
\hline Women's Economic Rights & 56 & 0.88 & 0.41 & 0.00 & 1.60 & Cingranelli and Richards (2010) \\
\hline Women’s Political Rights & 56 & 1.69 & 0.52 & 0.00 & 2.80 & Cingranelli and Richards (2010) \\
\hline Women’s Social Rights & 56 & 0.59 & 0.46 & 0.00 & 1.80 & Cingranelli and Richards (2010) \\
\hline SIGI (reversed) & 39 & 0.79 & 0.13 & 0.32 & 1.00 & Branisa et al. (2009) \\
\hline Family code (reversed) & 43 & 0.53 & 0.19 & 0.20 & 0.97 & Branisa et al. (2009) \\
\hline Civil liberties (reversed) & 47 & 0.67 & 0.32 & 0.00 & 1.00 & Branisa et al. (2009) \\
\hline Physical integrity (reversed) & 44 & 0.54 & 0.20 & 0.03 & 0.96 & Branisa et al. (2009) \\
\hline Son preference (reversed) & 48 & 0.78 & 0.27 & 0.00 & 1.00 & Branisa et al. (2009) \\
\hline Ownership rights & 48 & 0.59 & 0.25 & 0.00 & 1.00 & Branisa et al. (2009) \\
\hline Islam source of legislation & 53 & 0.26 & 0.45 & 0.00 & 1.00 & Ahmed and Gouda (forthcoming) \\
\hline Supremacy of Islam & 53 & 0.98 & 1.69 & 0.00 & 5.00 & Ahmed and Gouda (forthcoming) \\
\hline Muslims share & 56 & 0.71 & 0.32 & 0.00 & 1.00 & Parker (1997) \\
\hline Real GDP per capita & 56 & 8694.39 & 16007.34 & 453.99 & 86642.55 & $\begin{array}{c}\text { PENN World Table } 7.1 \\
\text { (Summers and Heston 1991) }\end{array}$ \\
\hline Democracy & 56 & 0.23 & 0.40 & 0.00 & 1.00 & Cheibub et al. (2010) \\
\hline $\begin{array}{l}\text { KOF index of globalization } \\
\text { (overall) }\end{array}$ & 55 & 48.60 & 11.69 & 26.09 & 76.69 & $\begin{array}{l}\text { Dreher (2006); Dreher et al. } \\
\text { (2008) }\end{array}$ \\
\hline $\begin{array}{l}\text { Oil production value per } \\
\text { capita }\end{array}$ & 56 & 1600.77 & 3940.78 & 0.00 & 20042.52 & EIA (2012), own calculation \\
\hline $\begin{array}{l}\text { Avg. years of total schooling } \\
\text { (\% of population aged } 15 \text { and } \\
\text { over) Male }\end{array}$ & 42 & 6.72 & 2.33 & 2.05 & 11.35 & Barro and Lee (2013) \\
\hline $\begin{array}{l}\text { Avg. years of total schooling } \\
\text { (\% of population aged } 15 \text { and } \\
\text { over) Male/Female }\end{array}$ & 42 & 6.25 & 2.58 & 1.60 & 11.46 & Barro and Lee (2013) \\
\hline $\begin{array}{l}\text { Avg. years of total schooling } \\
\text { (\% of population aged } 25 \text { and } \\
\text { over) Male }\end{array}$ & 42 & 6.36 & 2.52 & 1.50 & 11.53 & Barro and Lee (2013) \\
\hline $\begin{array}{l}\text { Avg. years of total schooling } \\
\text { (\% of population aged } 25 \text { and } \\
\text { over) Male/Female }\end{array}$ & 42 & 5.75 & 2.77 & 1.17 & 11.58 & Barro and Lee (2013) \\
\hline
\end{tabular}


Figure 1. Women's Economic, Political and Social Rights in countries where is Islam is the source of legislation (group 1) and where Islam is not the source of legislation.

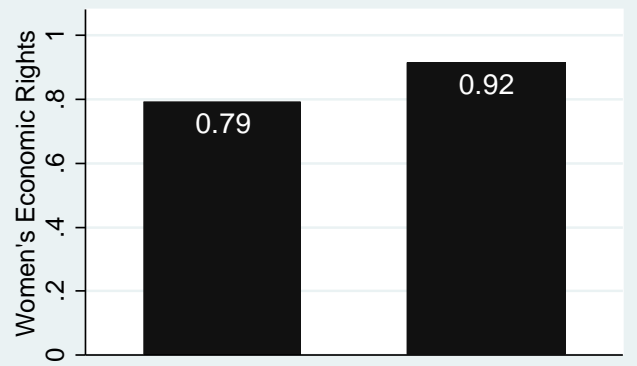

1

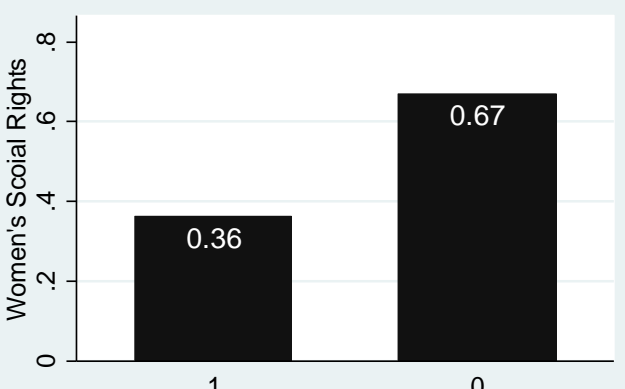

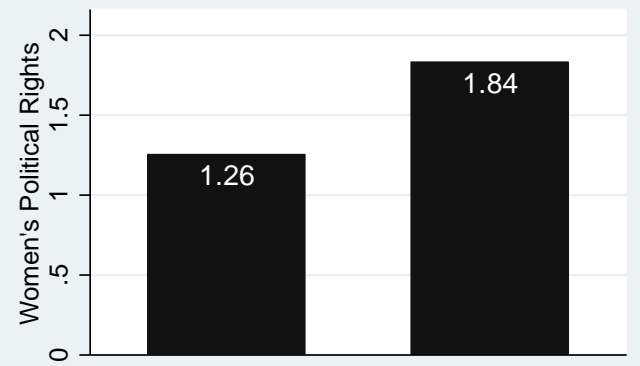

1

0

Women's Economic Rights: Number of countries where Islam is the source of legislation (group 1): 14, number of other countries: 39. T-test on means in subsamples with t-value 0.96 .

Women's Political Rights: Number of countries where Islam is the source of legislation (group 1): 14, number of other countries: 39. T-test on means in subsamples with t-value 4.01.

Women's Social Rights: Number of countries where Islam is the source of legislation (group 1): 14, number of other countries: 39. T-test on means in subsamples with t-value 2.18. 
Figure 2. Reversed SIGI (overall, family code and civil liberties) in countries where is Islam is the source of legislation (group 1) and where Islam is not the source of legislation.

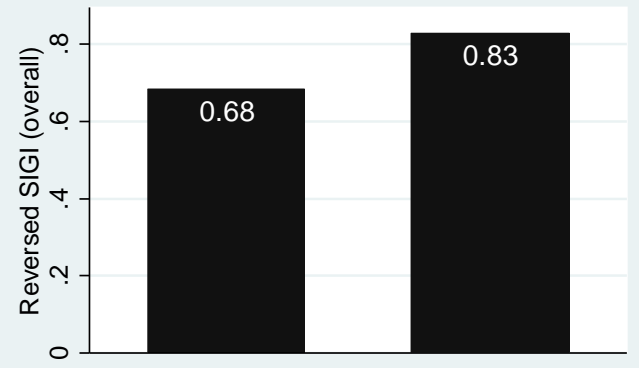

1

0

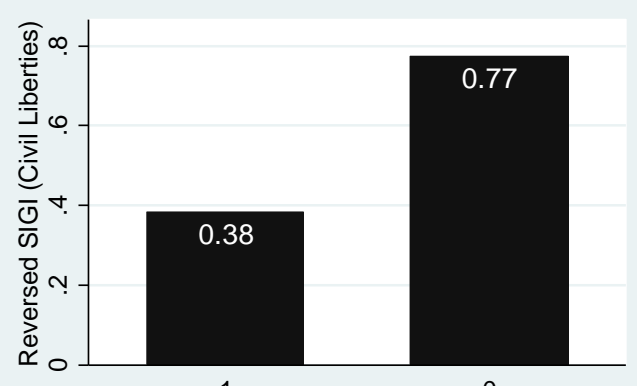

1

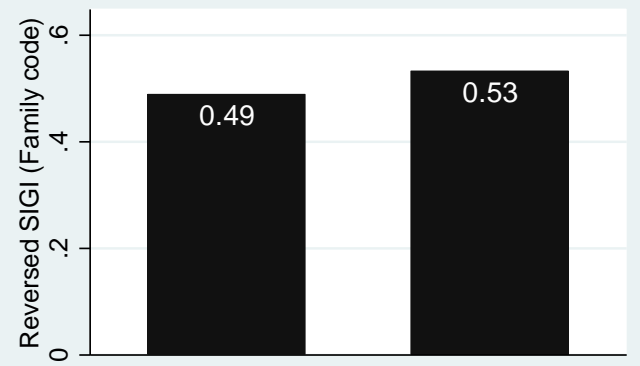

1

0

Reversed SIGI (overall): Number of countries where Islam is the source of legislation (group 1): 9, number of other countries: 27. T-test on means in subsamples with t-value 2.96.

Reversed family code sub-index: Number of countries where Islam is the source of legislation (group 1): 11, number of other countries: 29. T-test on means in subsamples with t-value 0.63 .

Reversed civil liberties sub-index: Number of countries where Islam is the source of legislation (group 1): 11, number of other countries: 33. T-test on means in subsamples with t-value 4.10. 
Figure 3. Reversed SIGI (physical integrity, son preference and ownership rights) in countries where is Islam is the source of legislation (group 1) and where Islam is not the source of legislation.

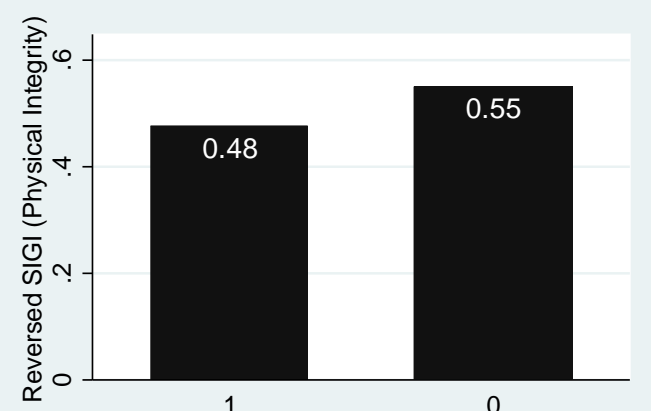

1

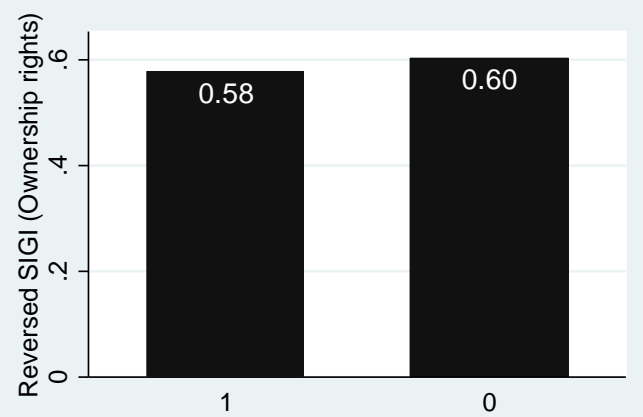

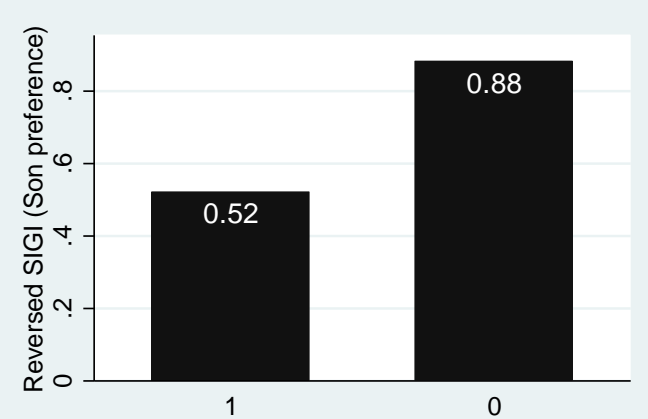

1

Reversed physical integrity sub-index: Number of countries where Islam is the source of legislation (group 1): 9, number of other countries: 32. T-test on means in subsamples with t-value 0.94.

Reversed son preference sub-index: Number of countries where Islam is the source of legislation (group 1): 11, number of other countries: 34. T-test on means in subsamples with t-value 5.02.

Reversed ownership rights sub-index: Number of countries where Islam is the source of legislation (group 1): 11, number of other countries: 34. T-test on means in subsamples with t-value 0.29. 
Table 1: Regression Results. Dependent variable: Women's Economic Rights

OLS with robust standard errors.

\begin{tabular}{lcccccc}
\hline & $(1)$ & $(2)$ & $(3)$ & $(4)$ & $(5)$ & $(6)$ \\
\hline Islam source of legislation & -0.121 & -0.183 & $-0.275^{*}$ & -0.251 & -0.254 & -0.194 \\
& $(-0.80)$ & $(-1.13)$ & $(-1.74)$ & $(-1.57)$ & $(-1.61)$ & $(-1.14)$ \\
Muslim share & & 0.209 & 0.170 & 0.166 & 0.255 & 0.221 \\
& & $(1.10)$ & $(1.01)$ & $(0.98)$ & $(1.60)$ & $(1.40)$ \\
log per capita GDP & & $0.113^{* *}$ & $0.122^{* * *}$ & 0.0559 & $0.114^{*}$ \\
& & & $(2.66)$ & $(2.79)$ & $(1.25)$ & $(1.88)$ \\
Democracy (Cheibub et al. 2010) & & & 0.125 & 0.0702 & 0.0785 \\
& & & & $(1.26)$ & $(0.75)$ & $(0.85)$ \\
Globalization (KOF index) & & & & 0.00661 & 0.00649 \\
& & & & $(1.19)$ & $(1.16)$ \\
Oil production value & & & & & -0.00003 \\
Constant & & & & & $(-1.55)$ \\
& & & & & -0.417 \\
Observations & & & & -0.189 & -0.00208 & $-0.45)$ \\
R-squared & $0.915^{* * *}$ & $0.783^{* * *}$ & -0.0821 & $(-0.01)$ & $(-1.05)$ \\
\hline
\end{tabular}

$t$ statistics in parentheses

${ }^{*} p<0.10,{ }^{* *} p<0.05,{ }^{* * *} p<0.01$

Table 2: Regression Results. Dependent variable: Women’s Political Rights

OLS with robust standard errors.

\begin{tabular}{|c|c|c|c|c|c|c|}
\hline & $(1)$ & $(2)$ & (3) & $(4)$ & $(5)$ & $(6)$ \\
\hline Islam source of legislation & $\begin{array}{c}-0.579 * * * \\
(-3.83)\end{array}$ & $\begin{array}{c}-0.450 * * \\
(-2.66)\end{array}$ & $\begin{array}{c}-0.364 * * \\
(-2.56)\end{array}$ & $\begin{array}{c}-0.369 * * \\
(-2.36)\end{array}$ & $\begin{array}{c}-0.457 * * * \\
(-3.39)\end{array}$ & $\begin{array}{c}-0.364 * * * \\
(-2.81)\end{array}$ \\
\hline Muslim share & & $\begin{array}{c}-0.441^{* *} \\
(-2.27)\end{array}$ & $\begin{array}{l}-0.404^{*} \\
(-1.85)\end{array}$ & $\begin{array}{c}-0.403^{*} \\
(-1.80)\end{array}$ & $\begin{array}{l}-0.195 \\
(-1.65)\end{array}$ & $\begin{array}{c}-0.248 * * \\
(-2.25)\end{array}$ \\
\hline log per capita GDP & & & $\begin{array}{l}-0.105 \\
(-1.61)\end{array}$ & $\begin{array}{l}-0.107 \\
(-1.49)\end{array}$ & $\begin{array}{c}-0.171^{* * *} \\
(-2.70)\end{array}$ & $\begin{array}{l}-0.0821 \\
(-1.24)\end{array}$ \\
\hline Democracy (Cheibub et al. 2010) & & & & $\begin{array}{c}-0.0243 \\
(-0.16)\end{array}$ & $\begin{array}{l}-0.149 \\
(-1.46)\end{array}$ & $\begin{array}{l}-0.136 \\
(-1.49)\end{array}$ \\
\hline Globalization (KOF index) & & & & & $\begin{array}{c}0.000732 \\
(0.13)\end{array}$ & $\begin{array}{c}0.000552 \\
(0.11)\end{array}$ \\
\hline Oil production value & & & & & & $\begin{array}{c}-0.0000401^{* *} \\
(-2.51)\end{array}$ \\
\hline Constant & $\begin{array}{c}1.836 * * * \\
(25.43) \\
\end{array}$ & $\begin{array}{c}2.115^{* * *} \\
(18.32) \\
\end{array}$ & $\begin{array}{c}2.919 * * * \\
(6.32) \\
\end{array}$ & $\begin{array}{c}2.939 * * * \\
(5.50) \\
\end{array}$ & $\begin{array}{c}3.373^{* * *} \\
(9.32) \\
\end{array}$ & $\begin{array}{c}2.733^{* * * *} \\
(6.38) \\
\end{array}$ \\
\hline Observations & 53 & 53 & 53 & 53 & 52 & 52 \\
\hline R-squared & 0.240 & 0.297 & 0.358 & 0.359 & 0.550 & 0.598 \\
\hline
\end{tabular}

$t$ statistics in parentheses

${ }^{*} p<0.10,{ }^{* *} p<0.05,{ }^{* * *} p<0.01$ 
Table 3: Regression Results. Dependent variable: Women's Social Rights

OLS with robust standard errors.

\begin{tabular}{|c|c|c|c|c|c|c|}
\hline & $(1)$ & $(2)$ & $(3)$ & $(4)$ & $(5)$ & $(6)$ \\
\hline Islam source of legislation & $\begin{array}{c}-0.307 * * \\
(-2.11)\end{array}$ & $\begin{array}{c}-0.264^{*} \\
(-1.72)\end{array}$ & $\begin{array}{l}-0.262 \\
(-1.50)\end{array}$ & $\begin{array}{l}-0.215 \\
(-1.18)\end{array}$ & $\begin{array}{l}-0.259 \\
(-1.40)\end{array}$ & $\begin{array}{l}-0.158 \\
(-0.80)\end{array}$ \\
\hline Muslim share & & $\begin{array}{l}-0.148 \\
(-0.64)\end{array}$ & $\begin{array}{l}-0.147 \\
(-0.62)\end{array}$ & $\begin{array}{l}-0.154 \\
(-0.66)\end{array}$ & $\begin{array}{l}-0.104 \\
(-0.43)\end{array}$ & $\begin{array}{l}-0.161 \\
(-0.68)\end{array}$ \\
\hline log per capita GDP & & & $\begin{array}{c}-0.00216 \\
(-0.04)\end{array}$ & $\begin{array}{c}0.0156 \\
(0.29)\end{array}$ & $\begin{array}{c}0.0258 \\
(0.36)\end{array}$ & $\begin{array}{c}0.123 \\
(1.67)\end{array}$ \\
\hline Democracy (Cheibub et al. 2010) & & & & $\begin{array}{l}0.249 \\
(1.56)\end{array}$ & $\begin{array}{l}0.220 \\
(1.39)\end{array}$ & $\begin{array}{l}0.234 \\
(1.56)\end{array}$ \\
\hline Globalization (KOF index) & & & & & $\begin{array}{c}-0.00402 \\
(-0.49)\end{array}$ & $\begin{array}{c}-0.00422 \\
(-0.54)\end{array}$ \\
\hline Oil production value & & & & & & $\begin{array}{c}-0.00004^{* *} \\
(-2.62)\end{array}$ \\
\hline Constant & $\begin{array}{c}0.671 * * * \\
(9.45)\end{array}$ & $\begin{array}{c}0.764 * * * \\
(4.52) \\
\end{array}$ & $\begin{array}{c}0.780 * \\
(1.74) \\
\end{array}$ & $\begin{array}{l}0.568 \\
(1.39) \\
\end{array}$ & $\begin{array}{l}0.672 \\
(1.60) \\
\end{array}$ & $\begin{array}{c}-0.0273 \\
(-0.06) \\
\end{array}$ \\
\hline Observations & 53 & 53 & 53 & 53 & 52 & 52 \\
\hline R-squared & 0.0854 & 0.0937 & 0.0937 & 0.136 & 0.141 & 0.200 \\
\hline
\end{tabular}

$t$ statistics in parentheses

${ }^{*} p<0.10,{ }^{* *} p<0.05,{ }^{* * *} p<0.01$

Table 4: Regression Results. Dependent variable: Gender equality = reversed SIGI (overall).

OLS with robust standard errors.

\begin{tabular}{|c|c|c|c|c|c|c|}
\hline & $(1)$ & $(2)$ & (3) & (4) & (5) & (6) \\
\hline Islam source of legislation & $\begin{array}{c}-0.144^{* *} \\
(-2.23)\end{array}$ & $\begin{array}{c}-0.169 * * \\
(-2.39)\end{array}$ & $\begin{array}{c}-0.199 * * \\
(-2.66)\end{array}$ & $\begin{array}{c}-0.203^{* *} \\
(-2.64)\end{array}$ & $\begin{array}{c}-0.178 * * \\
(-2.60)\end{array}$ & $\begin{array}{c}-0.163^{* *} \\
(-2.23)\end{array}$ \\
\hline Muslim share & & $\begin{array}{c}0.0878 * \\
(1.83)\end{array}$ & $\begin{array}{c}0.0573 \\
(1.12)\end{array}$ & $\begin{array}{c}0.0597 \\
(1.13)\end{array}$ & $\begin{array}{c}0.0706 \\
(1.54)\end{array}$ & $\begin{array}{c}0.0565 \\
(1.11)\end{array}$ \\
\hline log per capita GDP & & & $\begin{array}{c}0.0421^{* *} \\
(2.14)\end{array}$ & $\begin{array}{c}0.0409 * * \\
(2.07)\end{array}$ & $\begin{array}{c}-0.00546 \\
(-0.25)\end{array}$ & $\begin{array}{c}0.0104 \\
(0.45)\end{array}$ \\
\hline Democracy (Cheibub et al. 2010) & & & & $\begin{array}{c}-0.0127 \\
(-0.36)\end{array}$ & $\begin{array}{c}-0.0324 \\
(-0.94)\end{array}$ & $\begin{array}{c}-0.0289 \\
(-0.86)\end{array}$ \\
\hline Globalization (KOF index) & & & & & $\begin{array}{c}0.00665^{* *} \\
\quad(2.39)\end{array}$ & $\begin{array}{c}0.00710^{* *} \\
\quad(2.52)\end{array}$ \\
\hline Oil production value & & & & & & $\begin{array}{c}-0.00001 \\
(-1.15)\end{array}$ \\
\hline Constant & $\begin{array}{c}0.827 * * * \\
(43.36) \\
\end{array}$ & $\begin{array}{c}0.772 * * * \\
(26.74) \\
\end{array}$ & $\begin{array}{c}0.472 * * * \\
(3.16) \\
\end{array}$ & $\begin{array}{c}0.483^{* * *} \\
(3.22) \\
\end{array}$ & $\begin{array}{c}0.528 * * * \\
(4.10) \\
\end{array}$ & $\begin{array}{c}0.399 * * \\
(2.61) \\
\end{array}$ \\
\hline Observations & 36 & 36 & 36 & 36 & 36 & 36 \\
\hline R-squared & 0.205 & 0.239 & 0.344 & 0.345 & 0.455 & 0.475 \\
\hline
\end{tabular}

$t$ statistics in parentheses

${ }^{*} p<0.10,{ }^{* *} p<0.05,{ }^{* * *} p<0.01$ 
Table 5: Regression Results. Dependent variable: Gender Equality = reversed family code sub-index.

OLS with robust standard errors.

\begin{tabular}{|c|c|c|c|c|c|c|}
\hline & $(1)$ & $(2)$ & $(3)$ & $(4)$ & $(5)$ & $(6)$ \\
\hline Islam source of legislation & $\begin{array}{c}-0.0438 \\
(-0.79)\end{array}$ & $\begin{array}{c}-0.0968 \\
(-1.50)\end{array}$ & $\begin{array}{c}-0.167 * * \\
(-2.60)\end{array}$ & $\begin{array}{c}-0.165^{* *} \\
(-2.44)\end{array}$ & $\begin{array}{c}-0.155^{*} \\
(-2.01)\end{array}$ & $\begin{array}{c}-0.0988 \\
(-1.46)\end{array}$ \\
\hline Muslim share & & $\begin{array}{c}0.189 * * \\
(2.23)\end{array}$ & $\begin{array}{c}0.131 \\
(1.37)\end{array}$ & $\begin{array}{l}0.129 \\
(1.34)\end{array}$ & $\begin{array}{l}0.131 \\
(1.34)\end{array}$ & $\begin{array}{c}0.0806 \\
(0.79)\end{array}$ \\
\hline log per capita GDP & & & $\begin{array}{c}0.0796 * * * \\
(2.94)\end{array}$ & $\begin{array}{c}0.0805^{* * *} \\
(2.87)\end{array}$ & $\begin{array}{c}0.0677 \\
(1.59)\end{array}$ & $\begin{array}{c}0.131 * * \\
(2.67)\end{array}$ \\
\hline Democracy (Cheibub et al. 2010) & & & & $\begin{array}{c}0.00906 \\
(0.13)\end{array}$ & $\begin{array}{c}0.00681 \\
(0.09)\end{array}$ & $\begin{array}{c}0.0295 \\
(0.48)\end{array}$ \\
\hline Globalization (KOF index) & & & & & $\begin{array}{c}0.00163 \\
(0.47)\end{array}$ & $\begin{array}{c}0.00167 \\
(0.47)\end{array}$ \\
\hline Oil production value & & & & & & $\begin{array}{c}-0.00002^{* *} \\
(-2.38)\end{array}$ \\
\hline Constant & $\begin{array}{c}0.534^{* * *} \\
(13.30) \\
\end{array}$ & $\begin{array}{c}0.415^{* * *} \\
(7.45)\end{array}$ & $\begin{array}{l}-0.161 \\
(-0.92) \\
\end{array}$ & $\begin{array}{l}-0.169 \\
(-0.90) \\
\end{array}$ & $\begin{array}{l}-0.150 \\
(-0.75) \\
\end{array}$ & $\begin{array}{c}-0.600 * * \\
(-2.40) \\
\end{array}$ \\
\hline Observations & 40 & 40 & 40 & 40 & 40 & 40 \\
\hline R-squared & 0.0104 & 0.0857 & 0.285 & 0.286 & 0.290 & 0.419 \\
\hline
\end{tabular}

$t$ statistics in parentheses

${ }^{*} p<0.10,{ }^{* *} p<0.05,{ }^{* * *} p<0.01$

Table 6: Regression Results. Dependent variable: Gender Equality = reversed civil liberties sub-index.

OLS with robust standard errors.

\begin{tabular}{|c|c|c|c|c|c|c|}
\hline & $(1)$ & $(2)$ & (3) & (4) & (5) & (6) \\
\hline Islam source of legislation & $\begin{array}{c}-0.389 * * * \\
(-4.09)\end{array}$ & $\begin{array}{c}-0.379 * * * \\
(-3.49)\end{array}$ & $\begin{array}{c}-0.345^{* * *} \\
(-2.83)\end{array}$ & $\begin{array}{c}-0.334 * * \\
(-2.68)\end{array}$ & $\begin{array}{c}-0.361 * * * \\
(-2.77)\end{array}$ & $\begin{array}{c}-0.380 * * \\
(-2.65)\end{array}$ \\
\hline Muslim share & & $\begin{array}{c}-0.0408 \\
(-0.32)\end{array}$ & $\begin{array}{c}-0.0205 \\
(-0.16)\end{array}$ & $\begin{array}{c}-0.0248 \\
(-0.19)\end{array}$ & $\begin{array}{c}0.0302 \\
(0.24)\end{array}$ & $\begin{array}{c}0.0434 \\
(0.33)\end{array}$ \\
\hline log per capita GDP & & & $\begin{array}{c}-0.0374 \\
(-1.02)\end{array}$ & $\begin{array}{c}-0.0326 \\
(-0.86)\end{array}$ & $\begin{array}{c}-0.0402 \\
(-0.78)\end{array}$ & $\begin{array}{c}-0.0565 \\
(-1.00)\end{array}$ \\
\hline Democracy (Cheibub et al. 2010) & & & & $\begin{array}{c}0.0546 \\
(0.47)\end{array}$ & $\begin{array}{c}0.0223 \\
(0.20)\end{array}$ & $\begin{array}{c}0.0147 \\
(0.13)\end{array}$ \\
\hline Globalization (KOF index) & & & & & $\begin{array}{c}-0.00151 \\
(-0.29)\end{array}$ & $\begin{array}{c}-0.00160 \\
(-0.31)\end{array}$ \\
\hline Oil production value & & & & & & $\begin{array}{c}0.00001 \\
(0.71)\end{array}$ \\
\hline Constant & $\begin{array}{c}0.773 * * * \\
(16.32) \\
\end{array}$ & $\begin{array}{c}0.800 * * * \\
(10.11) \\
\end{array}$ & $\begin{array}{c}1.075^{* * *} \\
(3.87) \\
\end{array}$ & $\begin{array}{c}1.026 * * * \\
(3.54) \\
\end{array}$ & $\begin{array}{c}1.144^{* * *} \\
(3.91) \\
\end{array}$ & $\begin{array}{c}1.265^{* * *} \\
(3.63)\end{array}$ \\
\hline Observations & 44 & 44 & 44 & 44 & 43 & 43 \\
\hline R-squared & 0.286 & 0.287 & 0.305 & 0.309 & 0.342 & 0.346 \\
\hline
\end{tabular}

$t$ statistics in parentheses

${ }^{*} p<0.10,{ }^{* *} p<0.05,{ }^{* * *} p<0.01$ 
Table 7: Regression Results. Dependent variable: Gender Equality = reversed physical integrity sub-index. OLS with robust standard errors.

\begin{tabular}{lcccccc} 
& $(1)$ & $(2)$ & $(3)$ & $(4)$ & $(5)$ & $(6)$ \\
\hline Islam source of legislation & -0.0740 & -0.0978 & $-0.148^{*}$ & $-0.159^{*}$ & $-0.176^{* *}$ & $-0.176^{*}$ \\
& $(-0.96)$ & $(-1.09)$ & $(-1.76)$ & $(-1.86)$ & $(-2.05)$ & $(-1.80)$ \\
Muslim share & & 0.0884 & 0.0454 & 0.0477 & 0.109 & 0.109 \\
& & $(0.87)$ & $(0.43)$ & $(0.45)$ & $(1.05)$ & $(0.99)$ \\
log per capita GDP & & $0.0691^{* *}$ & $0.0648^{* *}$ & 0.0327 & 0.0325 \\
& & & $(2.50)$ & $(2.36)$ & $(0.91)$ & $(0.83)$ \\
Democracy (Cheibub et al. 2010) & & & -0.0459 & -0.0855 & -0.0856 \\
& & & & $(-0.55)$ & $(-1.03)$ & $(-1.04)$ \\
Globalization (KOF index) & & & & 0.00225 & 0.00225 \\
& & & & & $(0.64)$ & $(0.60)$ \\
Oil production value & & & & & 0.0000001 \\
Constant & & & & & $(0.01)$ \\
& & & & & 0.168 & 0.170 \\
Observations & & & & & $(0.88)$ & $(0.71)$ \\
R-squared & & & & & 40 & 40 \\
\hline
\end{tabular}

$t$ statistics in parentheses

${ }^{*} p<0.10,{ }^{* *} p<0.05,{ }^{* * *} p<0.01$

Table 8: Regression Results. Dependent variable: Gender Equality = reversed son preference sub-index. OLS with robust standard errors.

\begin{tabular}{|c|c|c|c|c|c|c|}
\hline & $(1)$ & $(2)$ & (3) & (4) & (5) & (6) \\
\hline Islam source of legislation & $\begin{array}{c}-0.360 * * * \\
(-4.65)\end{array}$ & $\begin{array}{c}-0.293^{* * *} \\
(-3.40)\end{array}$ & $\begin{array}{c}-0.275^{* *} \\
(-2.51)\end{array}$ & $\begin{array}{c}-0.283^{* *} \\
(-2.58)\end{array}$ & $\begin{array}{c}-0.269 * * \\
(-2.51)\end{array}$ & $\begin{array}{c}-0.256 * * \\
(-2.24)\end{array}$ \\
\hline Muslim share & & $\begin{array}{c}-0.249 * * * \\
(-3.21)\end{array}$ & $\begin{array}{c}-0.237 * * * \\
(-3.10)\end{array}$ & $\begin{array}{c}-0.236 * * * \\
(-3.01)\end{array}$ & $\begin{array}{c}-0.253^{* * *} \\
(-2.97)\end{array}$ & $\begin{array}{c}-0.262 * * * \\
(-2.96)\end{array}$ \\
\hline log per capita GDP & & & $\begin{array}{c}-0.0194 \\
(-0.61)\end{array}$ & $\begin{array}{c}-0.0232 \\
(-0.68)\end{array}$ & $\begin{array}{c}-0.0283 \\
(-0.61)\end{array}$ & $\begin{array}{c}-0.0175 \\
(-0.34)\end{array}$ \\
\hline Democracy (Cheibub et al. 2010) & & & & $\begin{array}{c}-0.0401 \\
(-0.51)\end{array}$ & $\begin{array}{c}-0.0303 \\
(-0.37)\end{array}$ & $\begin{array}{c}-0.0249 \\
(-0.28)\end{array}$ \\
\hline Globalization (KOF index) & & & & & $\begin{array}{c}0.00162 \\
(0.38)\end{array}$ & $\begin{array}{c}0.00168 \\
(0.40)\end{array}$ \\
\hline Oil production value & & & & & & $\begin{array}{c}-0.00001 \\
(-0.65)\end{array}$ \\
\hline Constant & $\begin{array}{c}0.882 * * * \\
(25.93)\end{array}$ & $\begin{array}{c}1.043^{* * *} \\
(32.31)\end{array}$ & $\begin{array}{c}1.184^{* * *} \\
(5.13)\end{array}$ & $\begin{array}{c}1.225^{* * *} \\
(4.78)\end{array}$ & $\begin{array}{c}1.190^{* * *} \\
(4.44)\end{array}$ & $\begin{array}{c}1.111^{* * *} \\
(3.52)\end{array}$ \\
\hline Observations & 45 & 45 & 45 & 45 & 44 & 44 \\
\hline R-squared & 0.369 & 0.443 & 0.450 & 0.453 & 0.458 & 0.461 \\
\hline
\end{tabular}

$t$ statistics in parentheses

${ }^{*} p<0.10,{ }^{* *} p<0.05,{ }^{* * *} p<0.01$ 
Table 9: Regression Results. Dependent variable: Gender Equality = reversed ownership rights sub-index. OLS with robust standard errors.

\begin{tabular}{|c|c|c|c|c|c|c|}
\hline & $(1)$ & $(2)$ & $(3)$ & $(4)$ & $(5)$ & $(6)$ \\
\hline Islam source of legislation & $\begin{array}{c}-0.0264 \\
(-0.28)\end{array}$ & $\begin{array}{l}-0.114 \\
(-1.11)\end{array}$ & $\begin{array}{c}-0.203^{*} \\
(-1.95)\end{array}$ & $\begin{array}{c}-0.202 * \\
(-1.87)\end{array}$ & $\begin{array}{c}-0.176 * \\
(-1.74)\end{array}$ & $\begin{array}{l}-0.173 \\
(-1.54)\end{array}$ \\
\hline Muslim share & & $\begin{array}{c}0.326^{* * *} \\
(3.14)\end{array}$ & $\begin{array}{c}0.265^{* * * *} \\
(2.80)\end{array}$ & $\begin{array}{c}0.265^{* * *} \\
(2.75)\end{array}$ & $\begin{array}{c}0.330^{* * *} \\
(3.39)\end{array}$ & $\begin{array}{c}0.328 * * * \\
(3.29)\end{array}$ \\
\hline log per capita GDP & & & $\begin{array}{c}0.0984 * * * \\
(3.19)\end{array}$ & $\begin{array}{c}0.0989 * * * \\
(3.12)\end{array}$ & $\begin{array}{c}0.0173 \\
(0.40)\end{array}$ & $\begin{array}{c}0.0199 \\
(0.47)\end{array}$ \\
\hline Democracy (Cheibub et al. 2010) & & & & $\begin{array}{c}0.00596 \\
(0.08)\end{array}$ & $\begin{array}{c}-0.0371 \\
(-0.49)\end{array}$ & $\begin{array}{c}-0.0359 \\
(-0.47)\end{array}$ \\
\hline Globalization (KOF index) & & & & & $\begin{array}{c}0.00936 * \\
(1.99)\end{array}$ & $\begin{array}{c}0.00937^{*} \\
(1.96)\end{array}$ \\
\hline Oil production value & & & & & & $\begin{array}{c}-0.000001 \\
(-0.09)\end{array}$ \\
\hline Constant & $\begin{array}{c}0.605^{* * *} \\
(13.77) \\
\end{array}$ & $\begin{array}{c}0.395^{* * * *} \\
(5.33)\end{array}$ & $\begin{array}{l}-0.323 \\
(-1.34) \\
\end{array}$ & $\begin{array}{l}-0.329 \\
(-1.30) \\
\end{array}$ & $\begin{array}{l}-0.163 \\
(-0.72) \\
\end{array}$ & $\begin{array}{l}-0.182 \\
(-0.71)\end{array}$ \\
\hline Observations & 45 & 45 & 45 & 45 & 44 & 44 \\
\hline R-squared & 0.00196 & 0.127 & 0.308 & 0.308 & 0.405 & 0.406 \\
\hline
\end{tabular}

$t$ statistics in parentheses

${ }^{*} p<0.10,{ }^{* *} p<0.05,{ }^{* * *} p<0.01$ 
Table A4: Correlation matrix gender equality indices (39 observations).

\begin{tabular}{|c|c|c|c|c|c|c|c|c|c|}
\hline & $\begin{array}{c}\text { CIRI } \\
\text { women's } \\
\text { economic } \\
\text { rights }\end{array}$ & $\begin{array}{c}\text { CIRI } \\
\text { women's } \\
\text { political } \\
\text { rights }\end{array}$ & $\begin{array}{c}\text { CIRI } \\
\text { women's } \\
\text { social } \\
\text { rights }\end{array}$ & $\begin{array}{l}\text { reversed } \\
\text { SIGI } \\
\text { (overall) }\end{array}$ & $\begin{array}{l}\text { reversed } \\
\text { family } \\
\text { code sub- } \\
\text { index }\end{array}$ & $\begin{array}{l}\text { reversed } \\
\text { civil } \\
\text { liberties } \\
\text { sub-index }\end{array}$ & $\begin{array}{l}\text { reversed } \\
\text { physical } \\
\text { integrity } \\
\text { sub-index }\end{array}$ & $\begin{array}{l}\text { reversed } \\
\text { son } \\
\text { preference } \\
\text { sub-index }\end{array}$ & $\begin{array}{l}\text { reversed } \\
\text { ownership } \\
\text { rights sub- } \\
\text { index }\end{array}$ \\
\hline CIRI women's economic rights & 1.00 & & & & & & & & \\
\hline CIRI women's political rights & 0.14 & 1.00 & & & & & & & \\
\hline CIRI women's social rights & 0.63 & 0.35 & 1.00 & & & & & & \\
\hline reversed SIGI (overall). & 0.50 & 0.24 & 0.46 & 1.00 & & & & & \\
\hline reversed family code sub-index & 0.41 & -0.04 & 0.36 & 0.66 & 1.00 & & & & \\
\hline reversed civil liberties sub-index & 0.40 & 0.55 & 0.57 & 0.65 & 0.23 & 1.00 & & & \\
\hline reversed physical integrity sub-index & 0.05 & 0.04 & 0.11 & 0.57 & 0.48 & 0.06 & 1.00 & & \\
\hline reversed son preference sub-index & 0.23 & 0.49 & 0.38 & 0.47 & -0.06 & 0.68 & -0.10 & 1.00 & \\
\hline reversed ownership rights sub-index & 0.45 & -0.14 & 0.33 & 0.71 & 0.67 & 0.26 & 0.35 & 0.05 & 1.00 \\
\hline
\end{tabular}

